\title{
Uji Kinerja Mesin Pemipil Jagung Berekelobot Produksi BBPP Batangkaluku
}

\section{(Performance Test for Production of Thresher Shelled Corn Machines BBPP Batangkaluku)}

\author{
Dhedy Ardianto $^{\left.1^{*}\right)}$, Iqbal ${ }^{2)}$ dan Abdul Waris ${ }^{3)}$ \\ 1) Program Studi Keteknikan Pertanian Universitas Hasanuddin \\ 2) Program Studi Keteknikan Pertanian Universitas Hasanuddin \\ ${ }^{3)}$ Program Studi Keteknikan Pertanian Universitas Hasanuddin \\ *Email korespondensi: dediardianto26@gmail.com
}

\begin{abstract}
ABSTRAK
Jagung tergolong tanaman serealia yang memiliki nilai jual tinggi, bernilai strategis, dan memiliki peluang untuk pengembangan karena jagung merupakan sumber utama protein dan karbohidrat setelah beras. Salah satu proses penanganan pasca panen jagung yang sangat penting terhadap hasil panen adalah proses pemipilan, di mana dalam proses pemipilan biji jagung dapat berpengaruh terhadap jumlah biji jagung rusak, kotoran, dan berperan dalam mempercepat proses pengeringan. Balai Besar Pelatihan Pertanian Batangkaluku telah mengembangkan mesin pemipil jagung dengan tenaga penggerak motor bakar yang dapat digunakan untuk memipil jagung tanpa memisahkan kelobotnya terlebih dahulu. Penelitian ini bertujuan untuk mengetahui kapasitas kerja mesin pemipil jagung berkelobot. Proses penelitian meliputi pengukuran dan perhitungan kapasitas pemipilan, tingkat kebersihan, persentase biji jagung rusak, serta konsumsi bahan bakar pada tiga kecepatan putaran poros pemipil yaitu $500 \mathrm{rpm}, 600 \mathrm{rpm}$, dan $700 \mathrm{rpm}$ dengan bahan masing-masing $10 \mathrm{~kg}$ jagung berkelobot. Hasil penelitian menunjukkan kapasitas pemipilan dipengaruhi oleh kecepatan putaran poros pemipil, dimana semakin tinggi kecepatan putaran poros pemipil maka kapasitas pemipilannya semakin besar. Kapasitas pemipilan tertinggi ditunjukkan oleh kecepatan putaran poros pemipil $700 \mathrm{rpm}$ yaitu sebesar 132,21 kg/jam.
\end{abstract}

Kata Kunci: Jagung Berkelobot, Kapasitas, Mesin Pemipil.

\section{PENDAHULUAN}

\section{Latar Belakang}

Jagung dengan nama latin (Zea mays

L.) merupakan salah satu tanaman pangan yang strategis dan memiliki nilai jual besar, serta memiliki potensi untuk dikembangkan karena jagung sebagai penghasil zat protein dan karbohidrat terbesar setelah beras. Pada tanaman jagung, hampir seluruh bagiannya dapat dimanfaatkan untuk berbagai hal yang diperlukan. Daun dan batang tanaman jagung dapat diolah menjadi makanan ternak, selain itu juga dapat dimanfaatkan sebagai bahan pupuk kompos atau hijau. Dalam skala industri batang jagung juga dimanfaatkan sebagai bahan pembuatan kertas (Purwanto, 2016).

Indonesia termasuk dalam kategori sepuluh negara produsen jagung terbesar di dunia setelah Mexico, Ukraina, Argentina, dan India berada pada posisi ke-8 dengan kontribusi hingga 1,99\% terhadap produksi jagung dunia berdasarkan data Food and Agriculture Organization (FAO). Produksi jagung di Indonesia yang tercatat dalam Badan Pusat Statistik dalam dua tahun 2014 
dan 2015 mencapai 19,01 juta ton dan 19,61 juta ton. Selain itu, rata-rata kenaikan produktivitas jagung dalam waktu selama 36 tahun mencapai hingga 3,72\% per tahun. Dalam waktu tersebut, produktivitas jagung nasional mengalami peningkatan dari 14,60 $\mathrm{Ku} / \mathrm{Ha}$ menjadi $52,85 \mathrm{Ku} / \mathrm{Ha}$ selama tahun 1980-2015 (Chafid, 2016).

Salah satu proses dalam penanganan pasca panen jagung yang sangat penting terhadap hasil panen adalah proses pemipilan, di mana dalam proses pelepasan biji jagung dari tongkolnya dapat berakibat pada kotoran, biji rusak, dan dapat mempercepat dalam proses pengeringan biji jagung. Proses pemipilan dapat dilakukan dengan metode manual dengan memisahkan biji dari tongkol satu per satu, baik dengan tangan ataupun dengan dibantu oleh sebuah alat sederhana. Selain itu, juga dapat menggunakan mesin pemipil jagung yang dewasa ini telah banyak dikembangkan oleh bengkel khusus alat dan mesin pertanian di desa, lembaga penelitian, perguruan tinggi maupun pada industri lokal. Mesin pemipil jagung yang saat ini beredar dan digunakan oleh petani adalah jenis mesin pemipil tanpa kelobot, dimana sebelum pengoperasian jagung dikupas dan dikeringkan terlebih dahulu. Namun mesin ini tidak dapat digunakan dalam kondisi hujan karena kandungan kadar air terlalu tinggi. Oleh karena itu, petani harus mengeluarkan biaya tambahan untuk membeli ataupun menyewa mesin pengering untuk mengurangi kadar air pada jagung sebelum dipipil.

Balai Besar Pelatihan Pertanian Batangkaluku telah mengembangkan sebuah pemipil jagung dilengkapi mesin dengan tenaga gerak motor bakar yang dapat digunakan untuk memipil jagung tanpa memisahkan kelobotnya terlebih dahulu. Namun demikian, sesuai dengan aturan yang dikeluarkan oleh Menteri Pertanian pada tahun 2007 nomor 5 Bab II Pasal 5 tentang pengujian alat dan mesin budidaya tanaman meliputi syarat dan tata serta pemberian sertifikat bahwa alsintan produksi dalam negeri dan/atau impor sebelum diedarkan ke tingkat petani ataupun untuk kepentingan industri harus dilakukan pengujian terlebih dahulu. Berdasarkan hal tersebut, maka dilakukan penelitian Uji Kinerja Alat Pemipil Jagung Berkelobot Produksi BBPP Batangkaluku untuk mengetahui kapasitas alat ini dalam memipil jagung tanpa kupas kelobot.

\section{Tujuan dan Kegunaan}

Penelitian ini bertujuan untuk mengetahui kapasitas kerja mesin pemipil jagung berkelobot yang diproduksi oleh BBPP Batangkaluku.

Kegunaan penelitian ini ialah sebagai bahan informasi bagi petani maupun peneliti untuk dijadikan sebagai bahan acuan dalam pengembangan alat yang serupa ke depannya.

\section{METODOLOGI PENELITIAN}

\section{Alat dan Bahan}

Alat yang digunakan pada penelitian ini meliputi, mesin pemipil jagung berkelobot, terpal, karung, tachometer, timbangan manual, timbangan digital (ketelitian 0,01 g), stopwatch, oven, gelas ukur, kamera, kertas spotlight, kertas label, aluminium foil, plastik cetik dan alat tulis.

Bahan yang digunakan pada penelitian ini adalah bahan bakar bensin dan jagung berkelobot varietas BISI-18 yang diperoleh dari Kabupaten Takalar, Sulawesi Selatan.

\section{Deskipsi Mesin Pemipil}

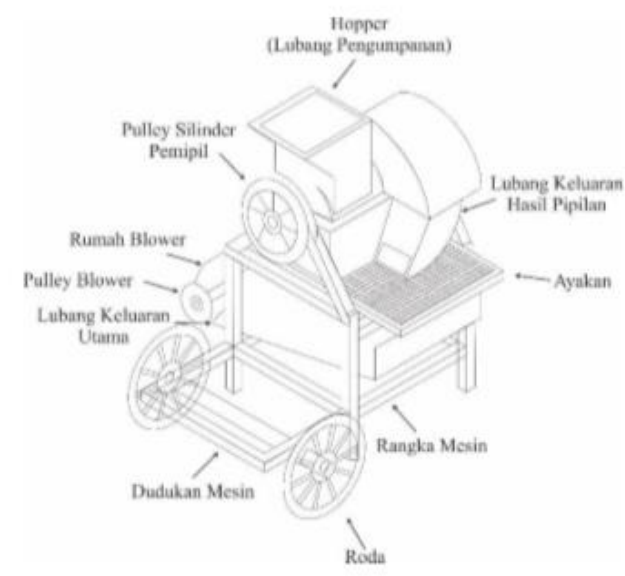

Gambar 1. Sketsa Mesin Pemipil Jagung Berkelobot 
Bagian-bagian mesin pemipil jagung berkelobot yang menjadi objek pada penelitian ini, yaitu sebagai berikut:

1. Rangka utama berfungsi untuk menopang komponen-komponen utama mesin yang memiliki panjang $144 \mathrm{~cm}$, lebar $120 \mathrm{~cm}$, dan tinggi $156 \mathrm{~cm}$.

2. Motor penggerak sebagai tenaga penggerak dari mesin pemipil yang memiliki daya 6 HP dan berbahan bakar bensin.

3. Silinder pemipil berfungsi untuk memisahkan biji jagung dengan tongkol kelobotnya yang memiliki panjang 74,6 $\mathrm{cm}$ dan berdiameter $16,2 \mathrm{~cm}$.

4. Hopper atau lubang pemasukan jagung berfungsi sebagai tempat masukan jagung berkelobot untuk selanjutnya dipipil oleh silinder pemipil.

5. Lubang pengeluaran jagung bersih berfungsi sebagai tempat keluarnya biji jagung hasil pipilan dengan ukuran, panjang $122 \mathrm{~cm}$, lebar bagian atas 74 $\mathrm{cm}$, dan lebar bagian bawah $39 \mathrm{~cm}$.

6. Lubang pengeluaran tongkol dan kelobot berfungsi sebagai tempat keluarnya tongkol dan kelobot dengan ukuran, panjang 22,6 cm dan lebar 16,8 $\mathrm{cm}$.

7. Ayakan berfungsi memisahkan biji jagung terpipil dari kotoran dan serpihan tongkol dengan ukuran, panjang 75,8 $\mathrm{cm}$, lebar $85,1 \mathrm{~cm}$, ukuran lubang saringan 3 mesh $(8 \mathrm{~mm})$ dan menggunakan model tipe getar.

8. Blower atau kipas penghembus berfungsi untuk memisahkan biji jagung hasil pipilan dengan kotoran yang masih terbawa setelah melewati lubang ayakan.

9. Puli berfungsi mentransmisikan daya dari motor penggerak menuju komponen yang digerakkan yaitu: silinder pemipil, ayakan, dan blower atau kipas penghembus, dengan bantuan V-belt.

10. Roda berfungsi untuk memudahkan mesin berpindah dari satu tempat ke tempat yang lain. Roda pada mesin ini menggunakan velg ukuran 17 inci dan dilengkapi ban.

\section{Prosedur Penelitian}

Prosedur penelitian meliputi persiapan alat dan bahan kemudian melakukan uji kinerja mesin melalui pengukuran dan perhitungan berbagai parameter pada tiga kecepatan putaran poros pemipil yaitu 500 rpm, $600 \mathrm{rpm}$, dan $700 \mathrm{rpm}$.

1. Pengukuran putaran motor penggerak

a. Ambil jagung berkelobot dan timbang sebanyak $10 \mathrm{~kg}$.

b. Tempatkan mesin pemipil di tengah hamparan terpal,

c. Tempel kertas spotlight pada puli silinder pemipil dan puli motor,

d. Nyalakan motor penggerak, kemudian atur kecepatan putaran poros pemipil hingga putaran optimum,

e. Ukur kecepatan putaran motor penggerak tanpa beban menggunakan tachometer dengan mengarahkan sensor pada kertas spotlight yang telah dipasang,

f. Masukkan jagung berkelobot ke dalam hopper (lubang pengumpanan),

g. Catat hasil pengukuran kecepatan putaran motor penggerak.

2. Pengukuran putaran silinder pemipil

a. Ambil jagung berkelobot dan timbang sebanyak $10 \mathrm{~kg}$,

b. Tempatkan mesin pemipil di tengah hamparan terpal,

c. Tempel kertas spotlight pada puli silinder dan puli motor,

d. Nyalakan motor penggerak, kemudian atur kecepatan putaran poros pemipil hingga putaran optimum,

e. Ukur kecepatan putaran poros pemipil tanpa beban menggunakan tachometer dengan mengarahkan sensor pada kertas spotlight yang telah dipasang,

f. Masukkan jagung berkelobot ke dalam hopper (lubang pengumpanan),

g. Catat hasil pengukuran kecepatan putaran poros pemipil.

3. Kapasitas pemipilan

a. Nyalakan mesin pemipil dan atur kecepatan putaran silinder pemipil hingga putaran optimum, 
b. Masukkan jagung berkelobot ke dalam hopper (lubang pengumpanan) secara berkesinambungan,

c. Ambil dan tampung biji jagung yang keluar melalui lubang pengeluaran hasil pipilan dalam waktu tertentu,

d. Timbang jagung berkelobot yang telah ditampung dalam waktu tertentu dan catat bobotnya,

e. Perlakuan dilakukan 3 kali ulangan.

4. Persentase biji jagung rusak

a. Ambil sampel sebanyak $250 \mathrm{~g}$ secara acak dari lubang pengeluaran utama setiap ulangan dan dilakukan terhadap 3 kali ulangan pemipilan,

b. Analisa sampel dan timbang biji jagung yang retak dan rusak serta kotoran.

5. Tingkat kebersihan

a. Sampel sebanyak $250 \mathrm{~g}$ di ambil secara acak dari lubang pengeluaran utama untuk setiap ulangan dan dilakukan terhadap 3 kali ulangan pemipilan,

b. Biji jagung (utuh dan rusak) dipisahkan dari kotoran dan benda asing kemudian ditimbang.

6. Konsumsi bahan bakar

Ukur volume bahan bakar dan waktu yang diperlukan selama proses pemipilan berlangsung setiap ulangan.

\section{Parameter Pengamatan}

Parameter yang diamati dalam penelitian ini antara lain sebagai berikut:

1. Kapasitas pemipilan

Berdasarkan SNI (7428:2008), kapasitas pemipilan alat pemipil jagung berkelobot dapat dihitung dengan menggunakan rumus:

$$
\mathrm{Kpo}=\mathrm{Wpo} \times \frac{60}{t}
$$

keterangan:

Kpo $=$ kapasitas keluaran pemipilan jagung ( $\mathrm{kg} / \mathrm{jam})$,

$\mathrm{Wpo}=$ berat total biji jagung yang ditampung pada lubang pengeluaran utama selama $\mathrm{t}$ menit (kg), dan $\mathrm{t}=$ waktu pemipilan yang sudah
ditentukan (menit).

2. Persentase biji jagung rusak

Berdasarkan SNI (4483:2013), biji jagung rusak merupakan biji jagung utuh maupun pecah yang mengalami kerusakan karena pengaruh biologis, fisik, dan enzimatis. Persentase biji jagung rusak menggunakan alat pemipil jagung berkelobot dapat dihitung dengan rumus (SNI 7428:2008):

$$
\mathrm{Wr}=\frac{W r 1-W r 2}{(W c-W k)} \times 100 \%
$$

keterangan:

$\mathrm{Wr}=$ persentase biji jagung rusak $(\%)$,

$\mathrm{Wr} 1=$ bobot biji jagung yang rusak karena pengeluaran dari mesin pemipil jagung (g),

$\mathrm{Wr} 2=$ bobot biji jagung rusak sebelum dipipil (g),

$\mathrm{Wc}=$ bobot contoh $(\mathrm{g})$ dan

$\mathrm{Wk}=$ bobot kotoran $(\mathrm{g})$.

3. Tingkat kebersihan

Tingkat kebersihan hasil pipilan menggunakan alat pemipil jagung berkelobot dapat dihitung dengan rumus:

$$
\mathrm{Tb}=\frac{W p 1}{W p} \times 100 \%
$$

keterangan:

$\mathrm{Tb}=$ tingkat kebersihan biji jagung $(\%)$,

$\mathrm{Wp} 1=$ bobot biji jagung (utuh dan rusak) yang keluar dari lubang pengeluaran utama $(\mathrm{g})$ dan

$\mathrm{Wp}=$ bobot total keluaran yang keluar dari lubang pengeluaran utama (g).

4. Konsumsi bahan bakar

Konsumsi bahan bakar dapat dihitung dengan menggunakan rumus:

$$
\mathrm{Fc}=\frac{V c}{t}
$$

keterangan:

$\mathrm{Fc}=$ bahan bakar minyak (1/jam),

$\mathrm{Vc}=$ kebutuhan bahan bakar (l) dan

$\mathrm{t}=$ waktu yang diperlukan untuk pemipilan (jam). 


\section{Diagram Alir Penelitian}

Langkah-langkah penelitian Uji Kinerja Mesin Pemipil Jagung Berkelobot Produksi BBPP Batangkaluku dapat dilihat pada diagram berikut.

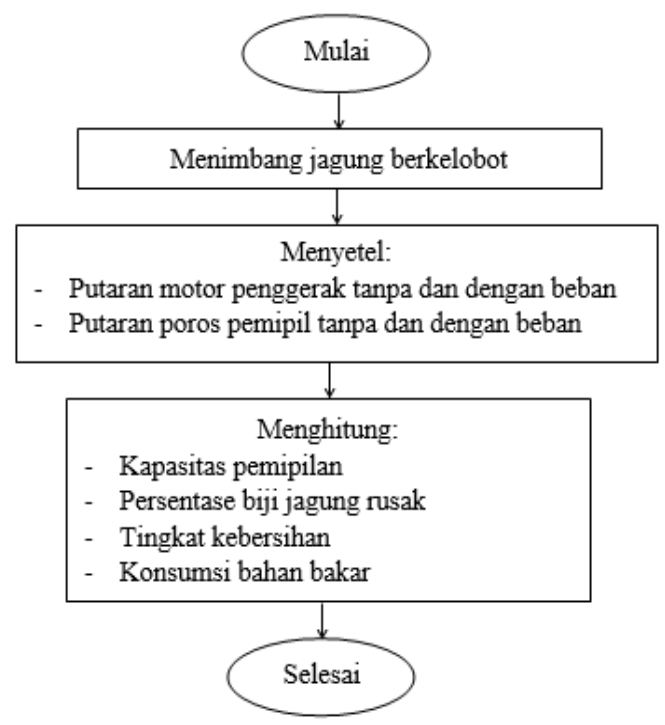

Gambar 2. Bagan alir penelitian

\section{HASIL DAN PEMBAHASAN}

\section{Kapasitas Pemipilan}

Proses pemipilan dilakukan pada tiga kecepatan putaran poros pemipil yaitu 500 rpm, $600 \mathrm{rpm}$, dan $700 \mathrm{rpm}$. Pemipilan dilakukan 3 kali pengulangan dengan memasukkan bahan masing-masing $10 \mathrm{~kg}$ jagung berkelobot. Perbandingan kapasitas pemipilan pada ketiga kecepatan ditunjukkan pada grafik berikut.

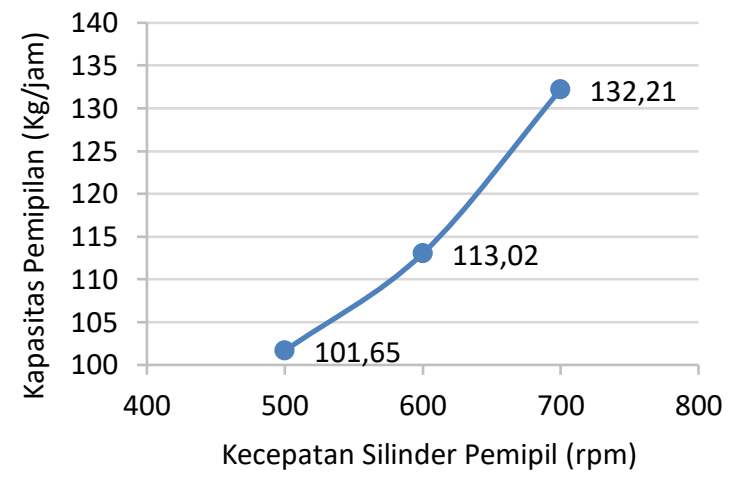

Gambar 3. Grafik kapasitas pemipilan (Kpo) mesin pemipil jagung berkelobot dengan variasi kecepatan putaran poros pemipil
Pada Gambar 3 dapat dilihat bahwa kecepatan putaran poros pemipil $500 \mathrm{rpm}$, $600 \mathrm{rpm}$ dan $700 \mathrm{rpm}$ menghasilkan kapasitas pemipilan antara lain sebesar $101,65 \mathrm{~kg} / \mathrm{jam}, 113,02 \mathrm{~kg} / \mathrm{jam}$ dan 132,21 $\mathrm{kg} / \mathrm{jam}$. Hal ini menunjukkan bahwa semakin tinggi kecepatan putaran poros pemipil, maka kapasitas pemipilannya semakin tinggi. Hal ini disebabkan oleh kemampuan gigi pemipil untuk memisahkan biji jagung dengan tongkol kelobotnya semakin besar seiring dengan meningkatnya kecepatan putaran.

Kapasitas pemipilan juga dipengaruhi oleh waktu pemipilan, dimana semakin rendah putaran silinder pemipil maka waktu yang dibutuhkan untuk memipil bahan semakin lama. Pernyataan ini didukung oleh hasil penelitian yang telah dilakukan oleh Umar (2010), dimana semakin tinggi putaran silinder perontok, kemungkinan terlepasnya biji jagung pada ujung tongkol semakin baik karena adanya keseimbangan lenturan sarangan dengan kecepatan putar silinder perontok. Sesuai dengan persyaratan unjuk kerja mesin pemipil jagung pada SNI 7428:2008 bahwa kapasitas pemipilan mesin dibagi menjadi 3 kelas yaitu kelas kecil untuk kapasitas pemipilan 100-150 kg/jam, kelas sedang dengan kapasitas 151-200 kg/jam, dan kelas besar untuk kapasitas pemipilan lebih besar dari $200 \mathrm{~kg} / \mathrm{jam}$. Berdasarkan Gambar 5, dapat dilihat bahwa kapasitas pemipilan pada penelitian ini berkisar pada 101,65$132,21 \mathrm{~kg} / \mathrm{jam}$ sehingga spesifikasinya digolongkan ke dalam kelas kecil.

Pengaruh kecepatan mesin terhadap kapasitas pemipilan juga dibuktikan melalui penelitian yang telah dilakukan oleh Syahputra (2017) yang menunjukkan bahwa kapasitas kerja suatu alat pemipil dan penggilingan jagung ditentukan oleh persentase kulit pada jagung, kadar air, kecepatan pemberian (feeding), dan kecepatan putaran alat. Hal ini sejalan dengan penelitian yang telah dipaparkan oleh Rasid et al. (2014), bahwa ada beberapa hal yang mempengaruhi proses pemipilan antara lain jumlah jagung 
bertongkol yang akan dipipil, kecepatan putaran, kadar air jagung bertongkol tersebut.

\section{Persentase Biji Jagung Rusak}

Persentase biji jagung rusak merupakan perbandingan biji jagung rusak yang keluar dari lubang keluaran utama terhadap seluruh hasil yang keluar dari lubang keluaran utama. Sedangkan menurut SNI (4483:2013), biji jagung rusak merupakan biji jagung utuh maupun pecah yang mengalami kerusakan karena pengaruh biologis, fisik, dan enzimatis.

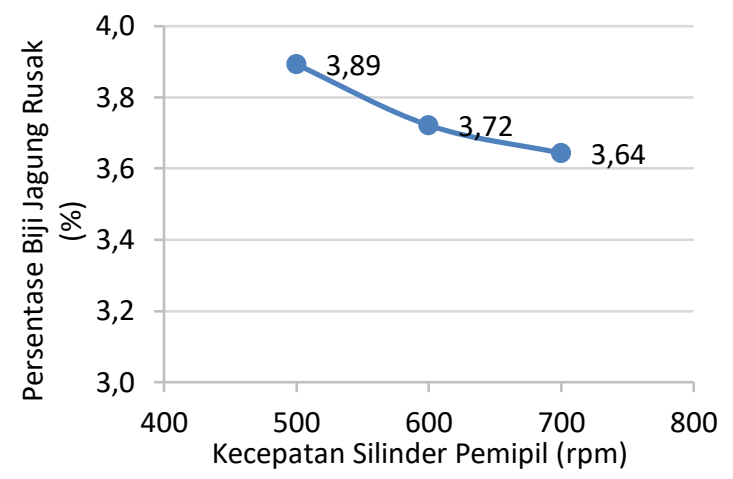

Gambar 4. Grafik persentase biji jagung rusak (Wr) dengan variasi kecepatan putaran poros pemipil.

Berdasarkan Gambar 4, dapat dilihat bahwa persentase biji jagung rusak pada tiga variasi kecepatan berturut-turut adalah $3,89 \%$, 3,72\% dan 3,64\%. Hal ini menunjukkan bahwa semakin rendah putaran silinder maka semakin tinggi persentase biji jagung rusak. Pada kecepatan 500 rpm, waktu yang dibutuhkan bahan untuk diproses dalam ruang pemipilan semakin lama sehingga gesekan antara biji jagung dengan gigi pemipil semakin besar. Hal ini mengakibatkan bertambahnya jumlah biji jagung retak sehingga persentase biji jagung rusak setelah dipipil semakin besar. Penelitian yang telah dilakukan oleh Umar (2010) menyatakan bahwa pecahnya butir rusak akibat biji jagung yang terjepit pada permukaan sarangan yang tidak elastis. Hal ini mengakibatkan terjadinya gesekan yang menyebabkan luka atau membuat biji jagung terbelah.

Hubungan kecepatan putaran mesin terhadap persentase jagung rusak yang tidak menggunakan gigi pemipil yang sesuai memberikan pengaruh yang signifikan sebagaimana yang dipaparkan pada hasil penelitian yang telah dilakukan oleh Rasid et al. (2014), bahwa pada pemipil jagung 4 gerigi hasil pipilan rusak tertinggi dengan persentase terbesar hanya $1,44 \%$ dari total berat pemipilan. Sedangkan jagung dengan pipilan sempurna dengan persentase terendah 98,56\%. Hal ini menunjukkan bahwa pemipil dengan hasil pipilan terbaik adalah pemipil yang mampu memipil dengan jumlah pipilan tidak rusak tertinggi dan hasil pipilan rusak terendah. Yang telah ditunjukkan hasilnya oleh pemipil dengan gerigi 4 yang dapat diisi dengan 3 tongkol jagung.

\section{Tingkat Kebersihan}

Perbandingan bobot biji jagung yang dihasilkan dari lubang keluaran utama terhadap total yang dihasilkan dari lubang keluaran utama. Adapun persentase tingkat kebersihan pada kecepatan putaran poros pemipil $500 \mathrm{rpm}, 600 \mathrm{rpm}$, dan $700 \mathrm{rpm}$ ditunjukkan oleh Gambar 7.

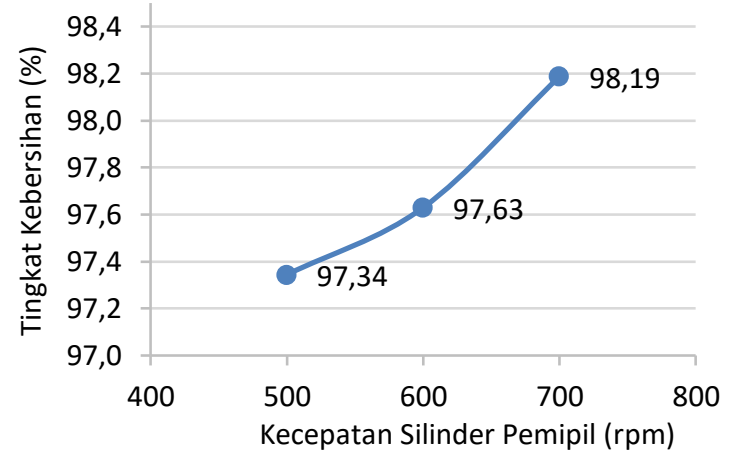

Gambar 5. Grafik persentase tingkat kebersihan $(\mathrm{Tb})$ dengan variasi kecepatan putaran poros pemipil.

Pada Gambar 5, menunjukkan bahwa kecepatan putaran poros pemipil $500 \mathrm{rpm}$ menghasilkan persentase tingkat kebersihan sebesar 97,34\%. Pada kecepatan poros pemipil 600 dan $700 \mathrm{rpm}$ menghasilkan tingkat kebersihan berturut-turut sebesar 97,63\% dan 98,19\%. Sehingga menunjukkan bahwa jagung yang telah dipipil tergolong bersih. Grafik tersebut menunjukkan bahwa semakin tinggi 
kecepatan putaran poros pemipil maka persentase tingkat kebersihannya semakin besar. Hal ini disebabkan oleh semakin tinggi kecepatan putaran poros pemipil maka semakin besar massa udara yang dibawa oleh blower (kipas pembersih). Sehingga kotoran yang terikut pada jagung yang dipipil lebih mudah untuk dihembuskan keluar.

Kadar air pada jagung juga mempengaruhi tingkat kebersihan jagung hasil pipilan, hal ini didukung oleh penelitian yang telah dilakukan oleh Jamilah et al. (2017), bahwa jagung yang telah panen menggunakan mesin pemanen jagung kombinasi masih bercampur dengan kotoran yang berasal dari kulit, batang dan bonggol jagung. Hal ini disebabkan oleh massa jenis kotoran menjadi lebih berat ketika kadar air semakin besar. Sehingga proses pembersihan menggunakan blower menjadi tidak optimal. Selain itu pada penelitian lain yang telah dilakukan oleh Harnas (2018), bahwa pada pengujian yang dilakukan kecepatan putaran pemipilan yang diambil adalah $700 \mathrm{rpm}$. Namun kecepatan putaran blower ini tidak mutlak harus menggunakan kecepatan putaran tersebut, tergantung dari jenis dan kondisi jagung yang digunakan.

\section{Konsumsi Bahan Bakar}

Konsumsi bahan bakar merupakan jumlah bahan bakar yang digunakan terhadap waktu selama proses pemipilan. Tingkat konsumsi bahan bakar pada kecepatan putaran poros pemipil $500 \mathrm{rpm}$, $600 \mathrm{rpm}$, dan $700 \mathrm{rpm}$ ditunjukkan pada grafik berikut.

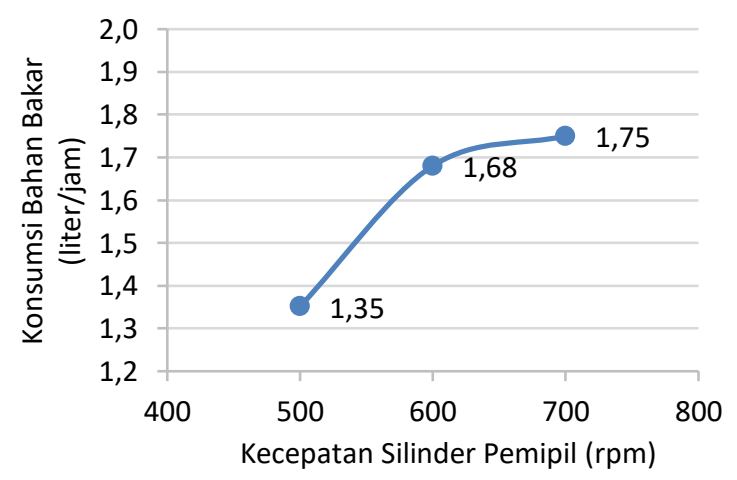

Gambar 6. Grafik persentase konsumsi bahan bakar $(\mathrm{Fc})$ dengan variasi kecepatan putaran poros pemipil
Berdasarkan Gambar 6, menunjukkan bahwa kecepatan putaran poros pemipil 500 rpm menunjukkan persentase bahan bakar yang dikonsumsi sebesar 1,35 liter/jam. Pada kecepatan putaran poros pemipil 600 dan 700 rpm menghasilkan konsumsi bahan bakar berturut-turut 1,68 liter/jam dan 1,75 liter/jam. Gambar 8 menunjukkan semakin tinggi kecepatan putaran poros pemipil, maka semakin tinggi tingkat konsumsi bahan bakarnya. Pernyataan ini sesuai dengan pendapat Saepuloh (2016), dimana semakin tinggi kecepatan putar mesin maka penggunaan bahan bakar semakin besar. Hal ini dikarenakan semakin tinggi kecepatan putar mesin maka jumlah bahan bakar yang dibutuhkan untuk proses pembakaran semakin tinggi.

Proses pembakaran yang terjadi di dalam silinder mesin dipengaruhi oleh putaran poros pemipil yang tinggi dan selanjutnya akan mempengaruhi tingkat kebutuhan bahan bakar mesin. Pernyataan ini sejalan dengan hasil penelitian yang telah dilakukan oleh Panjaitan (2013), bahwa besarnya konsumsi bahan bakar erat kaitannya dengan proses pembakaran di dalam silinder. Semakin sempurna proses pembakaran maka semakin efisien konsumsi bahan bakarnya. Terdapat beberapa faktor yang mempengaruhi proses pembakaran di dalam silinder ini, salah satunya adalah campuran bahan bakar dan udara. Apabila temperatur campuran bahan bakar dan udara naik, maka semakin mudah campuran bahan bakar dan udara tersebut terbakar. Dengan temperatur yang sesuai, campuran bahan bakar dan udara akan lebih homogen.

Selain itu pengaruh kecepatan putaran mesin terhadap tingkat konsumsi bahan bakar juga dibuktikan dengan penelitian yang telah dilakukan oleh Alwi (2017), bahwa tingkat konsumsi bahan bakar juga dipengaruhi oleh kecepatan. Kecepatan yang terlalu rendah cenderung mengkonsumsi bahan bakar banyak. 


\section{KESIMPULAN}

\section{Kesimpulan}

Berdasarkan penelitian yang telah dilakukan Berdasarkan penelitian yang telah dilakukan maka dapat ditarik kesimpulan sebagai berikut:

1. Semakin besar kecepatan putaran poros pemipil (rpm), maka kapasitas pemipilan semakin besar.

2. Mutu biji jagung pipilan yang diperoleh memiliki tingkat kebersihan biji jagung mencapai $97-98 \%$ dan persentase biji jagung yang rusak berkisar $3 \%$.

3. Semakin tinggi kecepatan putaran poros pemipil, maka semakin tinggi tingkat konsumsi bahan bakar.

\section{DAFTAR PUSTAKA}

Aqil, M. 2010. Pengembangan Metodologi untuk Penekanan Susut Hasil pada Proses Pemipilan Jagung. Balai Penelitian Tanaman Serealia: Maros.

Badan Pusat Statistik. 2018. Produksi Tanaman Pangan 2015. Nomor Publikasi: 05110.1605. ISSN/ISBN: 2088-6993. BPS Statistics: Jakarta.

Chafid, M. 2016. Outlook Komoditas Tanaman Pangan (Jagung). Pusat Data dan Sistem Informasi Pertanian Kementerian Pertanian: Jakarta.

Peraturan Menteri Pertanian No: 05/ Permentan/OT. 140/1/2007 tentang Syarat dan Tata Cara Pengujian dan Pemberian Sertifikat Alat dan Mesin Budidaya Tanaman.

Purwanto, S. 2016. Perkembangan Produksi dan Kebijakan dalam Peningkatan Produksi Jagung. Direktorat Budidaya Serelia: Jakarta.

Saepuloh, Eep. 2016. Pengaruh Putaran Mesin (Rpm) Terhadap Laju Konsumsi Bahan Bakar pada Mobil Nisan CMW 330. Universitas Muhammadiyah Pontianak: Pontianak.
SNI 7428:2008. Mesin Pemipil Jagung, Unjuk Kerja dan Cara Uji. Badan Standardisasi Nasional: Jakarta.

SNI 4483:2013. Jagung Bahan Pakan Ternak. Badan Standardisasi Nasional: Jakarta.

Suparlan, Marsudi dan Uning Budiharti. 2018. Evaluasi Teknis dan Ekonomis Mesin Pemipil Jagung Berkelobot. Jurnal Keteknikan Pertanian. Institut Pertanian Bogor: Bogor.

Umar, Sudirman. 2010. Kajian Alat Pemipil Jagung di Tingkat Petani (Study of Corn-Sheller on Farmer Level). Jurnal Agritech Vol. 23 No. 1 Halaman 2327. Badan Penelitian dan Pengembangan Pertanian: Jakarta. 